Int. J. Electrochem. Sci., 15 (2020) $1771-1787$

International Journal of

ELECTROCHEMICAL

SCIENCE

WWW.electrochemsci.org

\title{
Detection of Hydrochlorothiazide, Sulfamethoxazole, and Trimethoprim at Metal Oxide Modified Glassy Carbon Electrodes
}

\author{
Mohammad F. Khanfar ${ }^{1, *}$, Eyad S. M. Abu-Nameh ${ }^{2, *}$, Munib M. Saket ${ }^{1}$, Lujain T. Al Khateeb ${ }^{1}$, Akram \\ Al Ahmad ${ }^{2}$ Zeinab Asaad ${ }^{1}$, Zaina Salem ${ }^{1}$, and Nasim Alnuman ${ }^{3}$ \\ ${ }^{1}$ Pharmaceutical-Chemical Engineering Department, School of Applied Medical Sciences, German \\ Jordanian University, P.O.Box 35247 Amman 11180 Jordan \\ ${ }^{2}$ Department of Chemistry, Faculty of Science, Al-Balqa Applied University, Al-Salt 19117, Jordan \\ ${ }^{3}$ Biomedical Engineering Department, School of Applied Medical Sciences, German Jordanian \\ University, P.O.Box 35247 Amman 11180 Jordan \\ "E-mail: mohammad.khanfar@gju.edu.jo (M. F. Khanfar); abunameh@bau.edu.jo (E. S. M. Abu- \\ Nameh)
}

doi: $10.20964 / 2020.02 .35$

Received: 29 March 2019 / Accepted: 5 August 2019 / Published: 31 December 2019

\begin{abstract}
Molybdenum and manganese oxides are well-known electro-catalysts in fuel cells systems, they are usually used as anodic materials for the oxidation of low molecular weight alcohols. The utilization of $\mathrm{MoO}_{2}$ and $\mathrm{MnO}_{2}$ as catalysts in the pharmaceutical analysis is not common yet. In this study, bare glassy carbon electrodes were modified by the oxides by means of electrochemical deposition and the modified electrodes were used as catalysts for the electrochemical oxidation of sulfamethoxazole (SMX), trimethoprim (TMP), and hydrochlorothiazide (HCT). Well-resolved anodic peaks were reported for the analyzed pharmaceuticals when the $\mathrm{MoO}_{2} / \mathrm{GCE}$ was used for the simultaneous analysis of the SMX and TMP and when $\mathrm{MnO}_{2} / \mathrm{GCE}$ was utilized for the analysis of HCT. Analytical performance of the modified electrodes was evaluated based on the following statistical parameters; linearity ranges, correlation coefficients, limits of detection and quantitation, and recovery values. The prepared electrodes were used for the determination of the active ingredients in their pharmaceutical formulations and the reported activity was correlated to influence of the utilized $\mathrm{pH}$ on both structures of the used electrodes and the detected analytes.
\end{abstract}

Keywords: Molybdenum (IV) oxide, manganese (IV) oxide, sulfamethoxazole, trimethoprim, hydrochlorothiazide

FULL TEXT 
(C) 2020 The Authors. Published by ESG (www.electrochemsci.org). This article is an open access article distributed under the terms and conditions of the Creative Commons Attribution license (http://creativecommons.org/licenses/by/4.0/). 